\title{
Review \\ Is Glycogen Synthase Kinase-3 a Central Modulator in Mood Regulation?
}

\author{
Xiaohua Li*,' and Richard S Jope' \\ 'Department of Psychiatry and Behavioral Neurobiology, University of Alabama at Birmingham, Birmingham, AL, USA
}

\begin{abstract}
Little is known regarding the mechanisms underlying the complex etiology of mood disorders, represented mainly by major depressive disorder and bipolar disorder. The 1996 discovery that lithium inhibits glycogen synthase kinase-3 (GSK3) raised the possibility that impaired inhibition of GSK3 is associated with mood disorders. This is now supported by evidence from animal biochemical, pharmacological, molecular, and behavioral studies and from human post-mortem brain, peripheral tissue, and genetic studies that are reviewed here. Mood disorders may result in part from impairments in mechanisms controlling the activity of GSK3 or GSK3-regulated functions, and disruptions of these regulating systems at different signaling sites may contribute to the heterogeneity of mood disorders. This substantial evidence supports the conclusion that bolstering the inhibitory control of GSK3 is an important component of the therapeutic actions of drugs used to treat mood disorders and that GSK3 is a valid target for developing new therapeutic interventions. Neuropsychopharmacology (2010) 35, 2143-2I54; doi:10.1038/npp.2010.105; published online 28 July 2010
\end{abstract}

Keywords: glycogen synthase kinase-3; lithium; molecular and cellular neurobiology; mood disorders; neuropharmacology; signal transduction

\section{WHAT IS GLYCOGEN SYNTHASE KINASE-3 (GSK3)?}

GSK3 is a protein kinase originally identified and named for its ability to phosphorylate and inactivate the metabolic enzyme glycogen synthase (Embi et al, 1980). Subsequently, GSK3 was found to be a broadly influential enzyme in neural systems that modulates many aspects of neuronal function, such as gene expression, neurogenesis, synaptic plasticity, neuronal structure, and neuronal death and survival (Doble and Woodgett, 2003; Frame and Cohen, 2001; Jope and Johnson, 2004). Although commonly referred to as isoforms, the two GSK3 proteins, GSK3 $\alpha$ and GSK $3 \beta$, are paralogous proteins that are encoded by independent genes, but share $85 \%$ sequence homology, including 97\% homology in the kinase domain (Woodgett, 1990). Both GSK3 $\alpha$ and GSK3 $\beta$ are expressed throughout the brain (Yao et al, 2002), with GSK3 $\alpha$ especially abundant in the hippocampus, cerebral cortex, striatum, and the Purkinje cells of the cerebellum, and GSK3 $\beta$ more universally expressed in all brain regions (Allen Brain Atlas).

Over 50 substrates of GSK3 have been identified (Doble and Woodgett, 2003; Jope and Johnson, 2004). A majority of these substrates are primed by another kinase before being phosphorylated by GSK3 at the fourth residue $\mathrm{N}$-terminal to the primed site ( $\mathrm{pS} / \mathrm{TXXXpS/T})$, but there are also unprimed substrates phosphorylated by GSK3 on a Ser/Thr-Pro motif

*Correspondence: Dr X Li, Department of Psychiatry and Behavioral Neurobiology, University of Alabama at Birmingham, 1720 7th Avenue South, Sparks Center, 1075, Birmingham, AL 35294, USA, Tel: + 205-934- I I69, Fax: + 205-934-2500, E-mail: xili@uab.edu Received 27 April 2010; revised 4 June 2010; accepted 21 June 2010
(Doble and Woodgett, 2003). Several instances of substrates being phosphorylated by one GSK3 isoform but not the other have been identified, showing that the actions of the two isoforms are not always redundant (Chen et al, 2009; Force and Woodgett, 2009; Hoeflich et al, 2000; Liang and Chuang, 2006, 2007; Phiel et al, 2003; Wang et al, 1994).

Unlike many other protein kinases, both GSK3 isoforms are partially active in unstimulated cells, and they are regulated predominantly in an inhibitory manner by similar signaling mechanisms (Doble and Woodgett, 2003). Several protein kinases, such as Akt (Cross et al, 1995), protein kinase C (Goode et al, 1992), and protein kinase A (Fang et al, 2000; Li et al, 2000), phosphorylate GSK3 at an N-terminal serine residue, the serine-21 of GSK3 $\alpha$ and the serine-9 of GSK3 $\beta$ (Stambolic and Woodgett, 1994; Sutherland and Cohen, 1994; Sutherland et al, 1993). This modification inhibits the ability of GSK3 to phosphorylate its primed substrates (Cross et al, 1995; Kockeritz et al, 2006), and is targeted by many neuromodulators and psychotropic drugs (Figure 1), as discussed in the next two sections. In addition to inhibition by the $\mathrm{N}$-terminal serine phosphorylation, phosphorylation by p38 mitogen-activated protein kinase on the C-terminal serine-389 of GSK3 $\beta$ may also contribute to the inhibitory control of GSK3 (Thornton et al, 2008), but there is no information regarding pharmacological regulation of the C-terminal modification. Opposite to serine-phosphorylation, GSK3 activity is promoted by tyrosine phosphorylation at tyrosine-279 of GSK3 $\alpha$ and tyrosine-216 of GSK3 $\beta$, which facilitates access for substrate binding to GSK3 (Hughes et al, 1993). The function of this modification remains unresolved, as some evidence indicates that tyrosine-phosphorylation is an auto-phosphorylation event occurring when GSK3 is 
synthesized (Cole et al, 2004), while other evidence indicates that the tyrosine phosphorylation is a dynamic process regulated by intracellular signaling (Hartigan et al, 2001; Lesort et al, 1999b; Takahashi-Yanaga et al, 2004).

Besides being regulated by phosphorylation, GSK3 often associates with protein partners and phosphorylates substrates within these protein complexes. The best characterized example of this is the Wnt signaling pathway in which GSK3 is associated with the scaffold Axin, which also binds other proteins, notably $\beta$-catenin (Behrens et al, 1998; Rubinfeld et al, 1996). The proximity of GSK3 to $\beta$-catenin in the Axin protein complex allows $\beta$-catenin phosphorylation by GSK3, which facilitates $\beta$-catenin degradation by the proteasome (Davies et al, 2001; Henderson, 2000) (Figure 1). Wnt activation results in inactivation of GSK3 in the Axin complex by a mechanism that is still not well understood (Doble et al, 2007), which allows $\beta$-catenin stabilization and import into the nucleus in which it regulates gene expression (Papkoff and Aikawa, 1998). Therefore, protein complex formation is an important mechanism that allows regulation of GSK3 in a substrate-specific manner.

\section{REGULATION OF GSK3 BY LITHIUM AND OTHER PSYCHOTROPIC DRUGS}

The first evidence that GSK3 may be involved in mood disorders emerged from two reports showing that the classical mood stabilizer lithium is a direct inhibitor of GSK3 (Klein and Melton, 1996; Stambolic et al, 1996) by a magnesiumcompetitive mechanism (Ryves and Harwood, 2001). However, the direct effect of lithium measured in vitro is rather weak, as a therapeutically relevant concentration of lithium ( $1 \mathrm{mM}$ ) only inhibits GSK3 activity by approximately $25-50 \%$ depending on the magnesium concentration used in the kinase assay, in which $50 \%$ inhibition may be reached at physiological magnesium concentrations (Gurvich and Klein, 2002). Besides direct inhibition, lithium also inhibits GSK3 by increasing the inhibitory $\mathrm{N}$-terminal serine phosphorylation in cultured cells (Chalecka-Franaszek and Chuang, 1999), mouse brain (De Sarno et al, 2002), and human peripheral blood mononuclear cells (PBMCs) (Li et al, 2007a). Importantly, increased serine phosphorylation of GSK3 in mouse brain (De Sarno et al, 2002) and human PBMCs (Li et al,

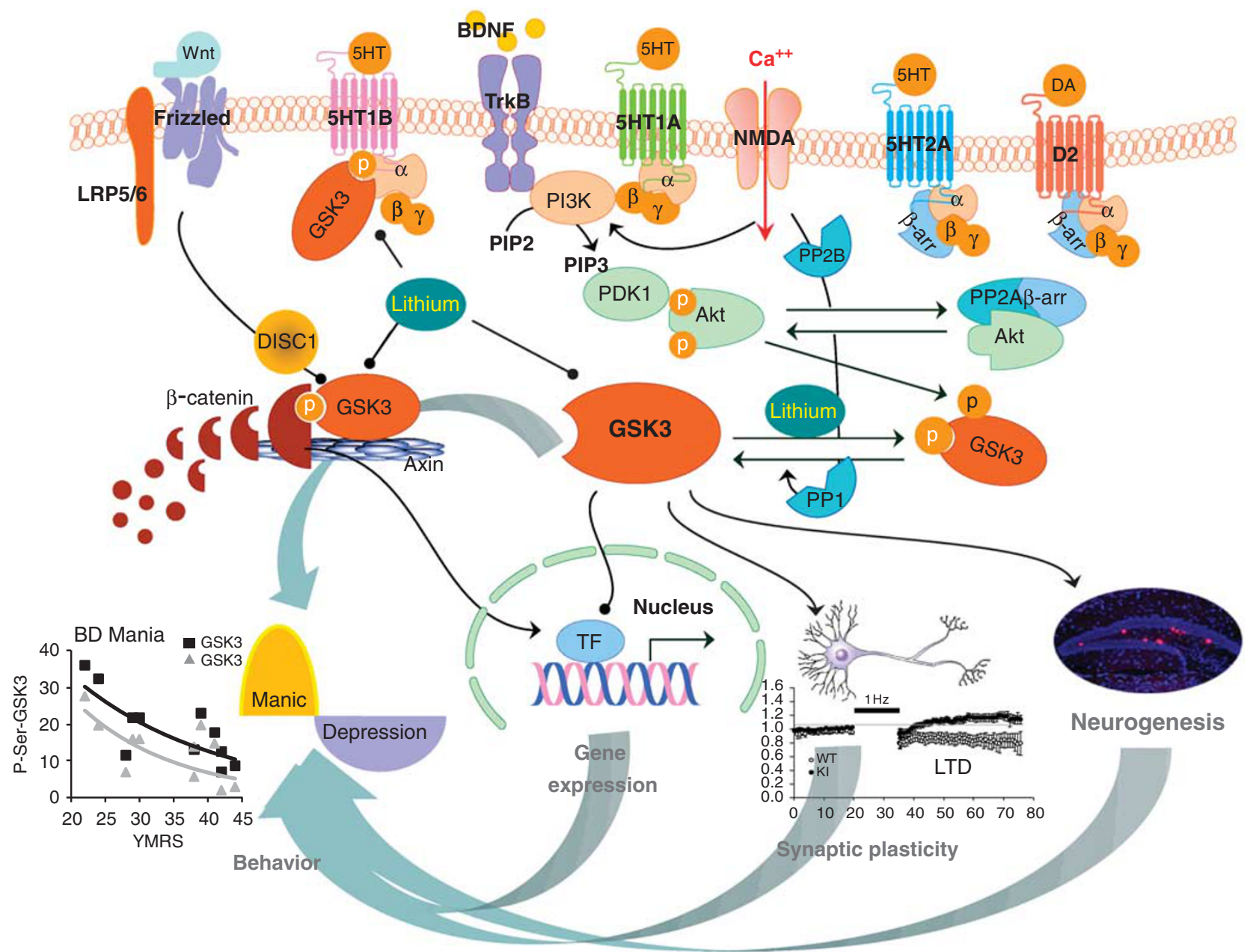

Figure I Schematic illustration of signaling pathways regulating GSK3 and functions of GSK3 related to mood regulation. GSK3 is regulated by BDNF, serotonin, and dopamine through the Akt signaling pathway, by the NMDA receptor through protein phosphatases, and by Wnt signaling in the Axin- $\beta$-catenin protein complex. Active GSK3 phosphorylates substrate proteins and affects gene expression, synaptic plasticity, and neurogenesis, which in turn regulate mood-related behaviors. Abbreviations: $\alpha, \beta, \gamma$, G-protein subunits; $\beta$-arr, $\beta$-arrestin; BD, bipolar disorder; BDNF, brain-derived neurotrophic factor; DA, dopamine; D2, type 2 dopamine receptor; DISCI, disrupted in schizophrenia I; GSK3, glycogen synthase kinase-3; 5HT, serotonin; 5HTIA, IB, 2A, serotonin receptor subtypes; LTD, long term depression; NMDA, N-methyl-D-aspartic acid; P, phosphorylated; PDKI, phosphoinositide-dependent kinase- I; PI3K, phosphatidylinositol-3-kinase; PPI, PP2A, PP2B, protein phosphatase I, 2A, and 2B; TF, transcription factors; TrKB, type B tropomyosin-receptor-kinase; YMRS, Young Mania Rating Scale. 
2007a) occurs with therapeutically relevant lithium administration $(0.8-1 \mathrm{mEq} / \mathrm{l}$ serum lithium concentration after 4 weeks of administration). Although the mechanism of this action by lithium has not been clearly established, it may involve the disruption of a $\beta$-arrestin/Akt/PP2A complex that results in Akt activation or an indirect inhibition of protein phosphatase 1 (PP1) (Beaulieu et al, 2008a; Chalecka-Franaszek and Chuang, 1999; Zhang et al, 2003). Lithium-induced increase in GSK3 serine-phosphorylation seems to amplify the direct inhibitory effect of lithium to produce a substantial inhibition of GSK3 in vivo with a therapeutic concentration of lithium (Figure 1). Besides these inhibitory effects on GSK3, other actions of lithium also have been suggested to contribute to its mood stabilizing effects, as detailed in other reviews (O'Brien and Klein, 2009; Quiroz et al, 2004; Rao et al, 2008).

The discovery that lithium is an inhibitor of GSK3 raised interest in determining if other mood stabilizers directly modulate GSK3 activity. Several studies reported that the anticonvulsant mood stabilizer valproate directly inhibited GSK3 activity (Chen et al, 1999b; Kim et al, 2005; Werstuck et al, 2004), but other studies did not find a direct inhibitory effect of valproate on GSK3 (Eickholt et al, 2005; Hall et al, 2002; Jin et al, 2005; Phiel et al, 2001). The reasons for these conflicting results remain unknown, but increasing evidence suggests that the mood stabilizing actions of valproate results, at least in part, from inhibition of histone deacetylases (HDACs) (Phiel et al, 2001). Interestingly, inhibition of HDACs by valproate or other HDAC inhibitors caused increased inhibitory serine-phosphorylation of GSK3 (Aubry et al, 2009; De Sarno et al, 2002; Kozlovsky et al, 2006; Lamarre and Desrosiers, 2008), raising the possibility that a combined action on HDAC and GSK 3 has a significant role in mood regulation by valproate. However, the therapeutic targets of valproate in mood disorders remain to be established. Few studies have tested if GSK3 is inhibited by other mood stabilizers, such as carbamazepine and lamotrigine. No evidence has been reported for inhibition of GSK3 by carbamazepine (Aubry et al, 2009; Mai et al, 2002; Ryves et al, 2005); one study in cultured cells found no effect of lamotrigine on GSK3 serine phosphorylation (Aubry et al, 2009); whereas chronic treatment (28 days) of mice with lamotrigine increased serine phosphorylation of GSK3 in the hippocampus and the cerebral cortex (unpublished data). Thus, it remains unclear if mood stabilizers other than lithium directly affect GSK3, but their actions on targets in signaling pathways upor down-stream of GSK3 may effectively counteract mood disturbance caused by dysregulated GSK3.

Clinically, a group of atypical antipsychotics have indications in mood disorders, either as anti-bipolar or adjunct antidepressant treatments (Derry and Moore, 2007; Philip et al, 2008). A majority of these agents, including risperidone, olanzapine, clozapine, quetiapine, and ziprasidone, increased serine phosphorylation of GSK3 in mouse brain (Alimohamad et al, 2005; Li et al, 2007b; Roh et al, 2007), and the effect was observed when administrated at low doses ( $\mathrm{Li}$ et $a \mathrm{l}, 2007 \mathrm{~b}$ ). Also interesting, a combination treatment with risperidone and fluoxetine enhanced the effect of either alone ( $\mathrm{Li}$ et al, 2007b). Clinically, atypical antipsychotics have implications not only in mood disorders, but are also used therapeutically in the treatment of psychotic disorders. One of the major pharmacological difference between atypical antipsychotics and conventional antipsychotics is the dual antagonistic action on 5-HT2 receptors and dopamine D2 receptors of atypical antipsychotics, in contrast to the primary D2 receptor blockade of conventional antipsychotics (Schotte et al, 1995). Haloperidol is the only conventional antipsychotic that has been reported to have an effect on brain GSK3, including altering the serine phosphorylation and increasing the protein level of GSK3 (Alimohamad et al, 2005; Kozlovsky et al, 2006; Roh et al, 2007). As discussed below, both 5-HT2 and D2 receptors regulate GSK3, it is thus possible that the therapeutic significance of this regulatory mechanism in mood or psychotic disorders depends on the brain regions, neurotransmitter systems, and the GSK3 regulatory mechanisms these agents target in different disease-specific brain abnormalities.

Not only mood stabilizers and antipsychotics inhibit GSK3, but substantial evidence has shown that monoamineregulating antidepressants also promote inhibitory control of GSK3. Administration of the monoamine reuptake inhibitor antidepressants fluoxetine and imipramine greatly increased the inhibitory serine phosphorylation of GSK3 in mouse brain (Beaulieu et al, 2008b; Li et al, 2004). The inhibitory effect of these antidepressants on GSK3 occurs within hours after an acute in vivo treatment, suggesting that this may be a response to the rapid increase in brain monoamines induced by these antidepressants, but whether the rapid inhibition of GSK3 is involved in the therapeutic actions of antidepressants that usually require chronic administration is a critical question remaining to be addressed.

These pharmacological studies show that inhibition of GSK3 is a common mechanism of action shared by several classes of drugs used in treating mood disorders (Table 1). A critical question remaining is to determine whether the effects of these pharmacological agents on GSK3 is related to their therapeutic actions in mood regulation, and how GSK3 serves as a target for both anti-manic and antidepressive treatments.

\section{EFFECTS OF NEUROMODULATORS ON GSK3}

In addition to being modulated by mood stabilizers and other psychotropics used in mood disorders, evidence for a role of GSK3 in mood disorders is further supported by findings that GSK3 is regulated by neuromodulators thought to be involved in mood disorders. For example, brain-derived neurotrophic factor (BDNF) is a wellrecognized neurotrophin with mood-regulating effects and is upregulated by antidepressants (Duman and Monteggia, 2006; Schmidt and Duman, 2007). Similar to other growth factors (Cross et al, 1995), BDNF binds to tyrosine kinase receptor $\mathrm{B}$ to activate phosphatidylinositol-3-kinase (PI3K) and Akt, and the latter phosphorylates the N-terminal serine of GSK3, thus inhibiting GSK3 activity (JohnsonFarley et al, 2006; Mai et al, 2002) (Figure 1). However, the behavioral effects of BDNF are brain region-dependent (Berton et al, 2006; Duman, 2004), thus it is important to determine if BDNF-induced inhibition of GSK3 mediates any BDNF-regulated behaviors.

Dysregulation of serotonin neurotransmission has long been thought to contribute to mood disorders (Jans et al, 2007), but the molecular basis of this consequence remains 
unclear. Recent evidence suggests that impaired inhibitory serine-phosphorylation of GSK3 may be a factor contributing to depression associated with dysregulated serotonergic activity. In mouse brain, enhancing serotonergic activity by D-fenfluramine administration or activation of serotonin type 1A (5-HT1A) receptors increased inhibitory serinephosphorylation of GSK3 in several brain regions (Li et al, 2004). This effect of serotonin is likely mediated by Akt because serotonin and 5-HT1A receptor agonists activate Akt through the PI3K-dependent pathway (Cowen et al, 2005; Polter et al, 2009). Conversely, in serotonin-deficient mice that carry a mutation in the tryptophan hydroxylase-2 gene equivalent to a rare human variant $(\mathrm{R} 441 \mathrm{H})$ identified in a few individuals with major depressive disorder (Zhang et al, 2005), serine phosphorylation of GSK3 is low and GSK3 activity is elevated (Beaulieu et al, 2008b). Regulation of GSK3 by serotonin may partly explain the mechanism of acute antidepressant treatment-induced GSK3 serine phosphorylation in brain (Beaulieu et al, 2008b; Li et al, 2004).

However, the effect of serotonergic activity on GSK3 is rather complicated because more than one serotonin receptor subtype is involved in regulating GSK3. Although serotonin type $2 \mathrm{~A}(5-\mathrm{HT} 2 \mathrm{~A})$ receptor stimulation had minimal effects on GSK3, blocking 5-HT2 receptors increased serine phosphorylation of GSK3 in several brain regions (Li et al, 2004). In addition, 5-HT2 receptor antagonist administration potentiated the 5-HT1A receptor agonist-induced increase in GSK3 serine phosphorylation (Li et al, 2004). Although an integrative mechanism remains

Table I Effects of Mood Disorder Therapeutic Drugs on GSK3

\begin{tabular}{|c|c|c|c|}
\hline Drug & Effect on GSK3 ( $\alpha$ and/or $\beta$ ) & Experimental treatment & References \\
\hline \multirow[t]{5}{*}{ Lithium } & $\downarrow$ Activity & In vitro & (Klein and Melton, 1996; Stambolic et al, 1996) \\
\hline & $\uparrow$ Ser-phosphorylation & In cells & $\begin{array}{l}\text { (Aubry et al, 2009; Chalecka-Franaszek and Chuang, 1999; } \\
\text { Jin et al, 2005) }\end{array}$ \\
\hline & & Acutely in animal brain & (Beaulieu et al, 2004) \\
\hline & & Chronically in animal brain & (De Sarno et al, 2002; Kozlovsky et al, 2006; Roh et al, 2005) \\
\hline & & In human PBMCs & (Li et al, 2007a) \\
\hline \multirow[t]{7}{*}{ Valproate } & $\downarrow$ Activity & In cells & (Chen et al, 1999b) \\
\hline & $\uparrow$ Ser-phosphorylation & In cells & (De Sarno et al, 2002) \\
\hline & & Acutely in animal brain & (Roh et al, 2005) \\
\hline & & Chronically in animal brain & (Li, unpublished data) \\
\hline & $\uparrow$ Total level & Subchronically in animal brains & (Kozlovsky et al, 2006) \\
\hline & No effect & In vitro & (Hall et al, 2002) \\
\hline & & In cells & (Eickholt et al, 2005; jin et al, 2005; Phiel et al, 200I) \\
\hline Carbamazepine & No effect & In cells & (Aubry et al, 2009; Mai et al, 2002; Ryves et al, 2005) \\
\hline \multirow[t]{2}{*}{ Lamotrigine } & $\uparrow$ Ser-phosphorylation & Chronically in animal brain & (Li, unpublished data) \\
\hline & No effect & In cells & (Aubry et al, 2009) \\
\hline Fluoxetine & $\uparrow$ Ser-phosphorylation & Acutely in animal brains & (Beaulieu et al, 2008b; Li et al, 2007b; Li et al, 2004) \\
\hline Imipramine & $\uparrow$ Ser-phosphorylation & Acutely in animal brains & (Li et al, 2007b; Li et al, 2004; Roh et al, 2005) \\
\hline \multirow[t]{5}{*}{ Clozapine } & $\uparrow$ Ser-phosphorylation & In cells & (Aubry et al, 2009; Kang et al, 2004) \\
\hline & & Acutely in animal brains & (Li et al, 2007b; Roh et al, 2007) \\
\hline & & Subacutely in animal brains & (Park et al, 20l0) \\
\hline & & Chronically in animal brains & (Alimohamad et al, 2005) \\
\hline & $\uparrow$ Total level & Chronically in animal brains & (Alimohamad et al, 2005; Kozlovsky et al, 2006) \\
\hline \multirow[t]{3}{*}{ Olanzapine } & $\downarrow$ Activity & In vitro & (Mohammad et al, 2008) \\
\hline & $\uparrow$ Ser-phosphorylation & In cells & (Aubry et al, 2009; Kim et al, 2008) \\
\hline & & Acutely in animal brains & (Li et al, 2007b) \\
\hline \multirow[t]{3}{*}{ Risperidone } & $\uparrow$ Ser-phosphorylation & Acutely in animal brains & (Li et al, 2007b) \\
\hline & & Chronically in animal brains & (Alimohamad et al, 2005) \\
\hline & $\uparrow$ Total level & Chronically in animal brains & (Alimohamad et al, 2005) \\
\hline Quetiapine & $\uparrow$ Ser-phosphorylation & Acutely in animal brains & (Li et al, 2007b) \\
\hline Ziprasidone & $\uparrow$ Ser-phosphorylation & Acutely in animal brains & (Li et al, 2007b) \\
\hline Aripiprazole & $\uparrow$ Ser-phosphorylation & In cells & (Park et al, 2009) \\
\hline \multirow[t]{5}{*}{ Haloperidol } & $\uparrow$ Ser-phosphorylation & Acutely in animal brains & (Roh et al, 2007) \\
\hline & & Chronically in animal brains & (Alimohamad et al, 2005) \\
\hline & $\downarrow$ Ser-phosphorylation & Chronically in animal brains & (Kozlovsky et al, 2006) \\
\hline & $\uparrow$ Total level & Chronically in animal brains & (Alimohamad et al, 2005) \\
\hline & No effect & In cells & (Park et al, 2009) \\
\hline
\end{tabular}


to be elucidated, it is possible that regulation of brain GSK3 by serotonin differs among brain regions and cell types depending on the serotonin receptor subtypes expressed, with the overall regulatory effect of serotonin on brain GSK3 involving a balanced response among several serotonin receptor subtypes (Figure 1).

GSK3 is also regulated by dopaminergic activity (Figure 1). Elevation of extracellular dopamine in dopamine transporter knockout mice was shown to reduce serine phosphorylation of GSK3 in the striatum, an effect that was reversed by administration of a dopamine D2 receptor antagonist (Beaulieu et al, 2004). Regulation of GSK3 by D2 receptor involves inactivation of Akt in a protein complex including the scaffolding protein $\beta$-arrestin2 and PP2A (Beaulieu et al, 2005). It is noteworthy that the effect of D2 receptor antagonists on GSK3 is similar to the effect of blocking 5-HT2 receptors, raising the possibility that the reported interaction of 5-HT2 receptors with $\beta$-arrestin2 (Schmid et al, 2008) may also be involved in the regulation of GSK3 by 5 -HT2 receptors.

Taken together, mood-regulating neuromodulators, exemplified by BDNF, serotonin, and dopamine, regulate GSK3 through different mechanisms of action, supporting the notion that disrupted GSK3 regulation occurs in mood disorders. The associations between behavioral effects and regulation of GSK3 by neuromodulators need to be clarified to fully understand the significance of GSK3 in mood disorders. In addition, the inhibitory serine phosphorylation of GSK3 seems to be a common mode of regulation by these neuromodulators, but the significance of this major GSK3 regulatory mechanism in mood-related behaviors remains to be determined.

\section{BEHAVIORAL STUDIES IN MICE WITH ALTERED GSK3 EXPRESSION OR ACTIVITY}

Behavioral studies in rodents using a variety of experimental strategies support the postulate that GSK3 is an important regulator of mood-related behaviors. GSK3 $\beta$ haploinsufficient (lacking one copy of the gene encoding GSK3 $\beta$ ) mice showed reduced immobility in the forced swim test, increased exploratory activity (O'Brien et al. 2004), and reduced amphetamine-induced hyperactivity (Beaulieu et al, 2004), similar to the behavioral effects of lithium in these tests. Reducing GSK3 $\beta$ in this animal model was also effective in normalizing the impaired tail suspension behavior in serotonin-deficient mice that otherwise have increased GSK3 activity (Beaulieu et al, 2008b). However, another group failed to replicate these behaviors reported in GSK3 $\beta$ haploinsufficient mice (Bersudsky et al, 2008). Conversely, transgenic mice postnatally overexpressing constitutively active S9A-GSK3 $\beta$ in neurons show hyperactivity in the open field test and increased acoustic startle response (Prickaerts et al, 2006), suggesting that excessive GSK3 $\beta$ could be a precipitating factor in heightened locomotor activity and sensory responses. However, instead of showing behaviors opposite to those of GSK3 $\beta$ haploinsufficient mice, GSK3 $\beta$ overexpressing mice also show decreased immobility in the forced swim test. An important factor complicating studies of these GSK3 $\beta$ overexpressing mice is that their brain size is reduced by approximately $20 \%$ (Spittaels et al, 2000, 2002), which may have confounding influences on their behaviors. A recent study focusing specifically on GSK $3 \alpha$ found that GSK $3 \alpha$ knockout mice show decreased exploratory activity, decreased immobility time in the forced swim test, and reduced aggressive behavior, among other phenotypes (Kaidanovich-Beilin et al, 2009), showing that both GSK3 isoforms have similar effects on behavior. However, a direct comparison of GSK $3 \alpha$ - and GSK3 $\beta$-selective regulation of behaviors is still lacking, a topic needing further investigation because each GSK3 isoform has independent functions (Chen et al, 2009; Liang and Chuang, 2006, 2007; Phiel et al, 2003; Wang et al, 1994).

As discussed above, the activity of GSK3 is predominantly regulated by posttranslational phosphorylation and regulation in protein complexes, whereas GSK3 protein expression is relatively stable (Doble and Woodgett, 2003). Although behavior findings in mice with altered expression of GSK3 have provided useful information linking GSK3 to regulating these behaviors, altering GSK3 expression may not accurately model a pathological condition in which GSK3 activity, but not expression, is dysregulated, such as by altered neuromodulators in mood disorders (Cousins et al, 2009; Duman, 2004; Jans et al, 2007). In addition, GSK3 $\alpha$ and GSK3 $\beta$ share similar regulatory mechanisms, and selectively manipulating one isoform could cause compensational changes in the other (Liang and Chuang, 2006, 2007; Lucas et al, 2001). Thus, behavioral changes of altered GSK3 $\alpha$ and GSK3 $\beta$ in combination should also be evaluated. Behavioral studies incorporating both these approaches have been conducted (Polter et al, 2010) in mice with serine-to-alanine mutations to block inhibitory serine-phosphorylation of both GSK3 $\alpha$ and GSK3 $\beta$ (GSK3 $\alpha / \beta^{21 \mathrm{~A} / 21 \mathrm{~A} / 9 \mathrm{~A} / 9 \mathrm{~A}}$ knockin mice) (McManus et al, 2005). A striking feature of these mice is that they show increased susceptibility to both amphetamine-induced hyperactivity and stress-induced depressive-like behaviors, whereas their baseline behaviors are similar to strain-matched wild-type mice. This suggests that insufficient inhibitory serine phosphorylation of GSK3 is a risk factor for developing mood-related behavioral disturbances, which complements the findings that lithium and many other psychotropics increase serine phosphorylation of GSK3 (Alimohamad et al, 2005; Beaulieu et al, 2008b; Chalecka-Franaszek and Chuang, 1999; De Sarno et al, 2002; Li et al, 2007a, b, 2004; Roh et al, 2007).

The robust behavioral effects of altered GSK3 suggest the importance of maintaining normal GSK3 activity in brain, and this is supported by several studies of behavior using GSK3 inhibitors that are either small molecule ATP competitors or a substrate-mimicking peptide that blocks substrate phosphorylation by GSK3 (Cohen and Goedert, 2004; Martinez et al, 2006; Meijer et al, 2004). Intracerebroventricular injection in rats of a small peptide GSK3 inhibitor, L803-mts, decreased immobility in the forced swim test (Kaidanovich-Beilin et al, 2004), suggesting that this GSK3 inhibitor has antidepressant-like actions. Subacute systemic administration of a small molecule GSK3 inhibitor ARA014418 not only reduced immobility in the forced swim test, but also reduced amphetamine-induced hyperactivity (Gould et al, 2004). Similar behavioral effects were also found with other GSK3 inhibitors (Beaulieu et al, 2004; Rosa et al, 2008), suggesting that these small molecule GSK3 inhibitors have 
similar mood-regulating effects as lithium, and may be developed for mood disorder treatment.

\section{GSK3 IN HUMAN BRAIN AND PERIPHERAL TISSUES}

Investigations of GSK3 in humans are necessary to confirm a relationship between abnormal regulation of GSK3 and mood disorders because animal behavioral measurements do not fully model mood disturbances in humans. A postmortem study with 40 brain samples from suicide and nonsuicide subjects revealed an increase in GSK3 $\beta$ activity and a decrease in Akt activity in depressed but not in nondepressed suicide subjects (Karege et al, 2007). Although two other studies reported no difference in GSK3 levels in post-mortem brains between bipolar disorder and healthy subjects (Kozlovsky et al, 2000; Lesort et al, 1999a), these studies did not investigate if the activity of GSK3 was altered. Assessing GSK3 activity or its serine phosphorylation may be difficult in post-mortem brains since in mice serine phosphorylation of GSK3 rapidly declines within minutes of death (Li et al, 2005). There are other limitations to using post-mortem brain tissues to evaluate GSK3 activity in mood disorders, as this cannot test mood statedependent changes in GSK3 activity during manic or depressive episodes, and pre-mortem medications may alter GSK3 phosphorylation and complicate the interpretation of post-mortem findings.

An alternative is to use peripheral tissues from live patients to assess GSK3, such as in PBMCs (Li et al, 2007a). In PBMCs from a small group of human subjects, serine phosphorylation of both GSK3 $\alpha$ and GSK3 $\beta$ in symptomatic bipolar disorder patients was lower than in healthy controls (Polter et al, 2010). Remarkably, reduction in serine phosphorylation of GSK3 also significantly correlated with severity of manic and depressive symptoms, suggesting that GSK3 activity is affected by mood states. Studies in several other cohorts measuring the expression of GSK3 mRNA and proteins generated varied results. The level of total GSK3 tends to be higher in type I bipolar manic patients than healthy controls in a Chinese population (unpublished data), whereas lower GSK3 mRNA was found in PBMCs of teenage suicide victims and lower GSK3 protein levels in platelets of bipolar patients (Pandey et al, 2010). Apparently, large cohorts in different mood states are needed to validate findings from human patients.

PBMCs have also been used to evaluate responses of GSK3 to mood disorder treatment. The level of phospho-Ser9GSK3 $\beta$ of bipolar patients stabilized on lithium treatment was eightfold higher than healthy controls who were not exposed to lithium (Li et al, 2007a), suggesting that GSK3 in PBMCs in bipolar disorder patients responds to lithium. In bipolar type I manic patients, a combination treatment with lithium and olanzapine also significantly increased serine phosphorylation of GSK3 (unpublished data), further supporting the preclinical findings showing that GSK3 activity is inhibited by mood stabilizing and antipsychotic treatments (Beaulieu et al, 2004; Li et al, 2007b, 2004; Polter et al, 2010).

Genetic variations in GSK3 also have been examined in mood disorders. A series of studies in an Italian population reported that a single-nucleotide polymorphism (SNP) in the promoter region of GSK3 $\beta$ (-50T/C) is associated with bipolar disorder (Benedetti et al, 2004a, b, 2005). The
C-variant was found to be linked to a later onset and better response to acute sleep deprivation in bipolar depressed patients, and a favorable response to lithium treatment for mood stabilization. In an independent study, the C-carriers of the $-50 \mathrm{~T} / \mathrm{C}$ SNP had better response to lithium augmenting treatment in acutely depressed antidepressant-resistant bipolar and major depressive disorder patients (Adli et al, 2007), whereas another study did not find an association of this SNP with the degree of prophylactic lithium response in bipolar disorder (Szczepankiewicz et al, 2006). Another pharmacogenomic study genotyped four SNPs (rs334558, rs13321783, rs2319398, and rs6808874) in the non-coding region of the GSK3 $\beta$ gene in 230 depressed patients and 415 controls in a Chinese population (Tsai et al, 2008), and identified significant association of three polymorphisms with 4-week antidepressant (fluoxetine or citalopram) therapeutic effects. In the four-locus haplotype analysis, the GSK3 $\beta$ TAGT carriers showed a poorer response to antidepressants, suggesting that they are likely non-responders to antidepressant treatment. A recent study evaluated the association of 15 GSK3 $\beta$ SNPs with brain structural changes in major depressive disorder (Inkster et al, 2009). The study found that the gray matter volume in the right hippocampus and bilateral superior temporal gyri is associated with a common SNP (rs6438552), an intronic polymorphism that regulates the selection of splice acceptor sites of GSK $3 \beta$ and thus affects GSK $3 \beta$ transcription. The lowered gray matter volume was specific to the AA genotypes of patients with major depressive disorder when compared to healthy controls. Therefore, GSK3 genetic variations may be involved in disease vulnerability and treatment response, and an important goal for future genetic research is to identify the functional correlates of these genetic variants on GSK3 function.

\section{HOW MIGHT INHIBITION OF GSK3 PROMOTE MOOD STABILIZATION?}

If, as much evidence suggests, GSK3 is dysregulated in mood disorders, a critical goal is to identify the substrates phosphorylated by GSK3 that mediate its regulation of mood. Some candidate proteins that are phosphorylated by GSK3 and seem to have mood-regulating functions have been identified. Prominent among these is the transcription factor cyclic AMP response element-binding protein (CREB), the most extensively studied transcription factor involved in mood disorders (Carlezon et al, 2005; Duman et al, 1997). The expression and activity of CREB are upregulated by lithium and antidepressants (Chen et al, 1999a; Mai et al, 2002; Nibuya et al, 1996; Ozaki and Chuang, 1997; Thome et al, 2000), and CREB overexpression in the dentate gyrus, has an antidepressant-like effect (Chen et al, 2001). Conversely, CREB is inactivated by GSK3-mediated phosphorylation on the serine-129 residue, and this inactivation is blocked by lithium treatment (Bullock and Habener, 1998; Fiol et al, 1994; Grimes and Jope, 2001).

$\beta$-Catenin is a major transcriptional modulator inhibited by GSK3 (Behrens et al, 1998; Rubinfeld et al, 1996), and is activated by GSK3 inhibitors that have mood-regulating effects, such as lithium (Hedgepeth et al, 1997; Stambolic 
et al, 1996). Transgenic mice overexpressing a constitutively active form of $\beta$-catenin in the adult CNS show behavioral changes similar to those observed after the administration of lithium, including decreased immobility time in the forced swim test and reduced D-amphetamine-induced hyperlocomotion, whereas forebrain-specific knockout of $\beta$-catenin caused a mild depressive-like behavior in mice (Gould et al, 2007, 2008). Recently, $\beta$-catenin was found to be regulated by disrupted in schizophrenia 1 (DISC1), which binds GSK3 to inhibit phosphorylation of $\beta$-catenin, allowing accumulation and activation of $\beta$-catenin (Mao et al, 2009). Genetic linkage studies have implicated mutations in DISC1 as a risk factor for mood disorders and other psychiatric diseases (Chubb et al, 2008; Millar et al, 2000; St Clair et al, 1990), and mutated DISC1 is unable to inhibit GSK3 to upregulate $\beta$-catenin. Modeling this by knocking-down DISC1 levels in mouse hippocampal dentate gyrus resulted in impaired neurogenesis, hyperactivity in the open field, and increased immobility in the forced swim test, which were reversed by a selective GSK3 inhibitor (Mao et al, 2009). Thus, regulation by DISC1 connects impaired inhibition of GSK3 with susceptibility to mood disorders.

As GSK3 regulates a large group of transcription factors and transcriptional modulators (Jope and Johnson, 2004), it could regulate the expression of genes involved in mood regulation and mood disorders, such as neurotrophins (Shaltiel et al, 2007). One example of this is that lithium increases BDNF expression in brain (Fukumoto et al, 2001). In cultured rat cortical neurons, therapeutic concentrations of lithium selectively increased the levels of exon IVcontaining BDNF mRNA, and the lithium-induced activation of promoter IV was mimicked by pharmacological inhibition of GSK3 or short interfering RNA-mediated gene silencing of GSK $3 \alpha$ or GSK3 $\beta$ (Yasuda et al, 2009). As substantial evidence shows that BDNF is involved in regulating mood and mediating effects of antidepressant and lithium (Duman, 2004; Post, 2007), inhibition of GSK3 may promote mood stabilization by increasing BDNF expression.

Not only is GSK3 regulated by serotonin, but GSK3 also selectively modulates the activity of serotonin receptors. GSK3 $\beta$ directly interacts with serotonin type $1 \mathrm{~B}$ (5-HT1B) receptors, but not 5-HT1A receptors, at a GSK3 consensus phosphorylation site (S154-XXX-T158) in the second intracellular loop of the receptor (Chen et al, 2009). GSK3 $\beta$-dependent phosphorylation of 5-HT1B receptors seems to be required for agonist-induced decrease in cAMP production. This finding extends several previous reports that lithium regulates 5-HT1B receptor activity (Januel et al, 2002; Massot et al, 1999; Redrobe and Bourin, 1999), and provides a mechanistic explanation for this action of lithium. As the primary action of 5-HT1B receptors located on axon terminals is to negatively regulate neurotransmitter release (Riad et al, 2000; Sari, 2004), altering neurotransmitter release by impaired control of GSK3 activity may be associated with mood disturbances. Identification of a direct interaction between GSK3 and 5-HT1B receptors also raises the likelihood that some other members of the large family of G-protein coupled receptors (GPCRs) may be regulated by GSK3. As GPCRs are the most common target for pharmacological interventions in the treatment of psychiatric disorders, future studies should examine the relationships between the proper control of GSK3 activity and the effect on pharmacological treatments targeting GPCRs.

An important component of neuroplasticity is neurogenesis, neural precursor cell proliferation and differentiation into neurons (Lie et al, 2004). Evidence that impaired neurogenesis in the hippocampus may be involved in mood disorders stems primarily from findings that neurogenesis is increased in mice by antidepressants (David et al, 2009; Malberg and Duman, 2003; Malberg et al, 2000; Manev et al, 2001; Santarelli et al, 2003; Warner-Schmidt and Duman, 2007), and is decreased by chronic stress that increases depressive-like behavior (Dranovsky and Hen, 2006; Malberg and Duman, 2003; McEwen, 2008). Lithium also increases neurogenesis (Chen et al, 2000; Hashimoto et al, 2003; Silva et al, 2008; Wexler et al, 2008), which may result from its inhibition of GSK3. This was shown in recent studies showing that neurogenesis was impaired in GSK3 knockin mice with blocked inhibitory serine-phosphorylation of GSK3 (Eom and Jope, 2009), and GSK3 deletion increased proliferation of neural progenitors (Kim et al, 2009). Therefore, disrupted neurogenesis in mood disorders can partially be a result of impaired control of GSK3.

GSK3 also regulates other processes associated with neuroplasticity, such as synaptic and structural plasticity (Citri and Malenka, 2008; Schloesser et al, 2008). In GSK3 knockin mice that lack the inhibitory serine phosphorylation of GSK3, NMDA receptor-dependent long-term depression (LTD) in area CA1 was converted to a slow onset long-term potentiation-like response (Polter et al, 2010). Interestingly, this conversion was previously noted in wildtype rats that were pre-exposed to acute swim stress (Maggio and Segal, 2009). Conversely, GSK3 inhibitors block the NMDA receptor-dependent induction of LTD (Peineau et al, 2007). In addition, GSK3 also modulates structural plasticity, such as growth cone formation and synaptogenesis. For example, inhibition of GSK3 by Wnt led to a decrease in the phosphorylation of microtubule-associated protein-1B and a concomitant decrease in microtubule stability (Salinas, 1999), whereas lithium treatment increased microtubule stability in neuronal growth cones (Goold et al, 1999). Although these neuroplasticity processes regulate neuronal maturation and adaptation, their relevance to mood disorders remains to be more firmly established, and further research is needed to determine if the influence of GSK3 on neuroplasticity is related to the pathophysiology or treatment of mood disorders.

One of the most well-established properties of GSK3 inhibitors is their neuroprotective actions, as previously reviewed (Beurel and Jope, 2006; Chuang, 2005). On a cellular level, the neuroprotective actions of GSK3 inhibitors are often experimentally identified by measuring cell survival in response to insults. For example, GSK3 inhibitors reduce many types of apoptosis-inducing insults, such as misfolded protein accumulation (Song et al, 2002) and DNA damage (Watcharasit et al, 2002). Although apoptosis is unlikely to contribute directly to mood disorder etiology, neuroprotection strengthens adaptive responses of cells to better withstand many types of stress, and enhances neuronal functions that counteract stress-induced mood disturbances. GSK3 inhibitors block a number of actions of GSK3 that impair neuronal function after stress. For example, by inhibiting the transcription factor HSF-1 (Chu et al, 1996), GSK3 reduces the expression of chaperone proteins, 
a major cellular protective mechanism against neuronal insults, and GSK3 inhibitors strengthen cellular responses to stress by upregulating the expression of chaperone proteins (Bijur and Jope, 2000; Ren et al, 2003). Similarly, GSK3 promotes, and GSK3 inhibitors counteract, impairments associated with DNA damage, exemplified by the nonhomologous end-joining DNA repair pathway that is promoted by lithium (Yang et al, 2009). Thus, along with promoting production and actions of neuroprotective neurotrophins (Machado-Vieira et $a l, 2009$ ) and $\beta$-catenin (Toledo et al, 2008), inhibition of GSK3 bolsters intracellular mechanisms that provide neuroprotection. Although these neuroprotective actions of GSK3 inhibitors are clearly important in counteracting neurodegenerative conditions such as ischemia, further research is needed to determine if they contribute to regulation of mood disturbances.

GSK3 has a strong regulatory effect on inflammation that is now recognized as having an important influence on the pathology and treatment of mood disorders, especially depression (Miller et al, 2009; Raison et al, 2006). Inflammatory molecules are often increased in depressed patients (Hayley et al, 2005; Lotrich et al, 2009; O'Brien et al 2007, 2006; Reichenberg et al, 2001), and in rodents, inflammation-induced depressive-like behaviors can be attenuated by antidepressants (Dantzer and Kelley, 2007; Dantzer et al, 2008; Rivest, 2009; Roumestan et al, 2007). A crucial role for GSK3 in promoting inflammation was first established by the finding that GSK3 promotes the production of several pro-inflammatory cytokines after stimulation of multiple types of Toll-like receptors in human monocytes, which are reduced by GSK3 inhibitors or by inducing GSK3 deficiency (Martin et al, 2005). Remarkably, GSK3 regulates oppositely the anti-inflammatory cytokine IL-10, because GSK3 inhibition increased IL-10 levels ( $\mathrm{Hu}$ et al, 2006; Martin et al, 2005). In vivo, the GSK3 inhibitors lithium and SB216763 rescued approximately $70 \%$ of mice from an otherwise $100 \%$ lethal inflammatory response to lipopolysaccharide (Martin et al, 2005). Subsequently, GSK3 inhibitors were found to reduce by $>90 \%$ inflammatory cytokine production in mouse primary astrocytes and microglia (Beurel and Jope, 2009; Yuskaitis and Jope, 2009). Thus, GSK3 strongly promotes inflammatory reactions, which may contribute to its role in mood disorders, and reducing GSK3-promoted production of inflammatory molecules may contribute to the therapeutic actions of mood stabilizers and antidepressants that inhibit GSK3.

\section{SUMMARY}

Cumulative evidence from in vitro measurements, pharmacological studies, animal behavioral tests, and investigations with human tissues strongly support the postulate that GSK3 has a pathological role in mood disorders and is likely a therapeutic target in mood disorder treatment. However, remaining questions must be addressed before GSK3 can be concluded to be a pathogenic molecule and therapeutic target in mood disorders. Although mood stabilizers, antidepressants, and antipsychotics can inhibit GSK3, it is important to determine if this inhibition of GSK3 is critical for their therapeutic actions. Perhaps most important is identifying the GSK3-regulated protein substrates that mediate the physiological and behavioral effects of GSK3 on mood regulation. Further investigation is required to understand how altered activity of GSK3 affects behavior, and to determine the mechanisms of how each mood state - manic or depressive - is affected by altered GSK3 activity. This emphasizes the need for human studies to determine if clinical findings support the ample preclinical evidence suggesting a link between dysregulated GSK3 and mood disorders, and if GSK3 could be a biomarker for differential diagnosis of mood disorders or a treatment predictor. Preclinical and clinical studies are also needed to test if selective GSK3 inhibitors are therapeutic for mood disorders. Only with such additional evidence will the role of dysregulated GSK3 in the etiology of mood disorders be firmly established, and clinical applications targeting GSK3, its regulatory signaling pathways, and its mood-regulating substrates be implemented.

\section{ACKNOWLEDGEMENTS}

This work was supported by NIH grants MH73723, MH86622 (XL), and MH38752 (RSJ).

\section{DISCLOSURE}

The authors declare no conflict of interest.

\section{REFERENCES}

Adli M, Hollinde DL, Stamm T, Wiethoff K, Tsahuridu M, Kirchheiner $\mathrm{J}$ et al (2007). Response to lithium augmentation in depression is associated with the glycogen synthase kinase 3-beta -50T/C single nucleotide polymorphism. Biol Psychiatry 62: 1295-1302.

Alimohamad H, Rajakumar N, Seah YH, Rushlow W (2005). Antipsychotics alter the protein expression levels of beta-catenin and GSK-3 in the rat medial prefrontal cortex and striatum. Biol Psychiatry 57: 533-542.

Aubry JM, Schwald M, Ballmann E, Karege F (2009). Early effects of mood stabilizers on the Akt/GSK-3beta signaling pathway and on cell survival and proliferation. Psychopharmacology (Berl) 205: 419-429.

Beaulieu JM, Marion S, Rodriguiz RM, Medvedev IO, Sotnikova TD, Ghisi V et al (2008a). A beta-arrestin 2 signaling complex mediates lithium action on behavior. Cell 132: 125-136.

Beaulieu JM, Sotnikova TD, Marion S, Lefkowitz RJ, Gainetdinov RR, Caron MG (2005). An Akt/beta-arrestin 2/PP2A signaling complex mediates dopaminergic neurotransmission and behavior. Cell 122: 261-273.

Beaulieu JM, Sotnikova TD, Yao WD, Kockeritz L, Woodgett JR, Gainetdinov RR et al (2004). Lithium antagonizes dopaminedependent behaviors mediated by an AKT/glycogen synthase kinase 3 signaling cascade. Proc Natl Acad Sci USA 101: 5099-5104.

Beaulieu JM, Zhang X, Rodriguiz RM, Sotnikova TD, Cools MJ, Wetsel WC et al (2008b). Role of GSK3 beta in behavioral abnormalities induced by serotonin deficiency. Proc Natl Acad Sci USA 105: 1333-1338.

Behrens J, Jerchow BA, Wurtele M, Grimm J, Asbrand C, Wirtz R et al (1998). Functional interaction of an axin homolog, conductin, with beta-catenin, APC, and GSK3beta. Science 280: 596-599.

Benedetti F, Bernasconi A, Lorenzi C, Pontiggia A, Serretti A, Colombo C et al (2004a). A single nucleotide polymorphism in glycogen synthase kinase 3-beta promoter gene influences onset of illness in patients affected by bipolar disorder. Neurosci Lett 355: 37-40.

Benedetti F, Serretti A, Colombo C, Lorenzi C, Tubazio V, Smeraldi E (2004b). A glycogen synthase kinase 3-beta promoter gene single 
nucleotide polymorphism is associated with age at onset and response to total sleep deprivation in bipolar depression. Neurosci Lett 368: 123-126.

Benedetti F, Serretti A, Pontiggia A, Bernasconi A, Lorenzi C, Colombo $C$ et al (2005). Long-term response to lithium salts in bipolar illness is influenced by the glycogen synthase kinase 3-beta -50 T/C SNP. Neurosci Lett 376: 51-55.

Bersudsky Y, Shaldubina A, Kozlovsky N, Woodgett JR, Agam G, Belmaker RH (2008). Glycogen synthase kinase-3beta heterozygote knockout mice as a model of findings in postmortem schizophrenia brain or as a model of behaviors mimicking lithium action: negative results. Behav Pharmacol 19: 217-224.

Berton O, McClung CA, Dileone RJ, Krishnan V, Renthal W, Russo SJ et al (2006). Essential role of BDNF in the mesolimbic dopamine pathway in social defeat stress. Science 311: 864-868.

Beurel E, Jope RS (2006). The paradoxical pro- and anti-apoptotic actions of GSK3 in the intrinsic and extrinsic apoptosis signaling pathways. Prog Neurobiol 79: 173-189.

Beurel E, Jope RS (2009). Lipopolysaccharide-induced interleukin-6 production is controlled by glycogen synthase kinase- 3 and STAT3 in the brain. J Neuroinflammation 6: 9.

Bijur GN, Jope RS (2000). Opposing actions of phosphatidylinositol 3-kinase and glycogen synthase kinase-3beta in the regulation of HSF-1 activity. J Neurochem 75: 2401-2408.

Bullock BP, Habener JF (1998). Phosphorylation of the cAMP response element binding protein CREB by cAMP-dependent protein kinase A and glycogen synthase kinase-3 alters DNAbinding affinity, conformation, and increases net charge. Biochemistry 37: 3795-3809.

Carlezon Jr WA, Duman RS, Nestler EJ (2005). The many faces of CREB. Trends Neurosci 28: 436-445.

Chalecka-Franaszek E, Chuang DM (1999). Lithium activates the serine/threonine kinase Akt-1 and suppresses glutamate-induced inhibition of Akt-1 activity in neurons. Proc Natl Acad Sci USA 96: 8745-8750.

Chen AC, Shirayama Y, Shin KH, Neve RL, Duman RS (2001). Expression of the cAMP response element binding protein (CREB) in hippocampus produces an antidepressant effect. Biol Psychiatry 49: 753-762.

Chen B, Wang JF, Hill BC, Young LT (1999a). Lithium and valproate differentially regulate brain regional expression of phosphorylated CREB and c-Fos. Brain Res Mol Brain Res 70: 45-53.

Chen G, Huang LD, Jiang YM, Manji HK (1999b). The mood-stabilizing agent valproate inhibits the activity of glycogen synthase kinase-3. J Neurochem 72: 1327-1330.

Chen G, Rajkowska G, Du F, Seraji-Bozorgzad N, Manji HK (2000). Enhancement of hippocampal neurogenesis by lithium. J Neurochem 75: 1729-1734.

Chen L, Salinas GD, Li X (2009). Regulation of serotonin 1B receptor by glycogen synthase kinase-3. Mol Pharmacol 76: 1150-1161.

Chu B, Soncin F, Price BD, Stevenson MA, Calderwood SK (1996). Sequential phosphorylation by mitogen-activated protein kinase and glycogen synthase kinase 3 represses transcriptional activation by heat shock factor-1. J Biol Chem 271: 30847-30857.

Chuang DM (2005). The antiapoptotic actions of mood stabilizers: molecular mechanisms and therapeutic potentials. Ann NY Acad Sci 1053: 195-204.

Chubb JE, Bradshaw NJ, Soares DC, Porteous DJ, Millar JK (2008). The DISC locus in psychiatric illness. Mol Psychiatry 13: 36-64.

Citri A, Malenka RC (2008). Synaptic plasticity: multiple forms, functions, and mechanisms. Neuropsychopharmacology 33: 18-41.

Cohen P, Goedert M (2004). GSK3 inhibitors: development and therapeutic potential. Nat Rev Drug Discov 3: 479-487.

Cole A, Frame S, Cohen P (2004). Further evidence that the tyrosine phosphorylation of glycogen synthase kinase-3 (GSK3) in mammalian cells is an autophosphorylation event. Biochem J 377: 249-255.

Cousins DA, Butts K, Young AH (2009). The role of dopamine in bipolar disorder. Bipolar Disord 11: 787-806.

Cowen DS, Johnson-Farley NN, Travkina T (2005). 5-HT receptors couple to activation of Akt, but not extracellular-regulated kinase (ERK), in cultured hippocampal neurons. J Neurochem 93: 910-917.
Cross DA, Alessi DR, Cohen P, Andjelkovich M, Hemmings BA (1995). Inhibition of glycogen synthase kinase-3 by insulin mediated by protein kinase B. Nature 378: 785-789.

Dantzer R, Kelley KW (2007). Twenty years of research on cytokineinduced sickness behavior. Brain Behav Immun 21: 153-160.

Dantzer R, O'Connor JC, Freund GG, Johnson RW, Kelley KW (2008). From inflammation to sickness and depression: when the immune system subjugates the brain. Nat Rev Neurosci 9: 46-56.

David DJ, Samuels BA, Rainer Q, Wang JW, Marsteller D, Mendez I et al (2009). Neurogenesis-dependent and -independent effects of fluoxetine in an animal model of anxiety/depression. Neuron 62: 479-493.

Davies G, Jiang WG, Mason MD (2001). The interaction between beta-catenin, GSK3beta and APC after motogen induced cell-cell dissociation, and their involvement in signal transduction pathways in prostate cancer. Int J Oncol 18: 843-847.

De Sarno P, Li X, Jope RS (2002). Regulation of Akt and glycogen synthase kinase-3 beta phosphorylation by sodium valproate and lithium. Neuropharmacology 43: 1158-1164.

Derry S, Moore RA (2007). Atypical antipsychotics in bipolar disorder: systematic review of randomised trials. BMC Psychiatry 7: 40.

Doble BW, Patel S, Wood GA, Kockeritz LK, Woodgett JR (2007). Functional redundancy of GSK-3alpha and GSK-3beta in Wnt/ beta-catenin signaling shown by using an allelic series of embryonic stem cell lines. Dev Cell 12: 957-971.

Doble BW, Woodgett JR (2003). GSK-3: tricks of the trade for a multi-tasking kinase. J Cell Sci 116(Part 7): 1175-1186.

Dranovsky A, Hen R (2006). Hippocampal neurogenesis: regulation by stress and antidepressants. Biol Psychiatry 59: 1136-1143.

Duman RS (2004). Role of neurotrophic factors in the etiology and treatment of mood disorders. Neuromolecular Med 5: 11-25.

Duman RS, Heninger GR, Nestler EJ (1997). A molecular and cellular theory of depression. Arch Gen Psychiatry 54: 597-606.

Duman RS, Monteggia LM (2006). A neurotrophic model for stressrelated mood disorders. Biol Psychiatry 59: 1116-1127.

Eickholt BJ, Towers GJ, Ryves WJ, Eikel D, Adley K, Ylinen LM et al (2005). Effects of valproic acid derivatives on inositol trisphosphate depletion, teratogenicity, glycogen synthase kinase-3beta inhibition, and viral replication: a screening approach for new bipolar disorder drugs derived from the valproic acid core structure. Mol Pharmacol 67: 1426-1433.

Embi N, Rylatt DB, Cohen P (1980). Glycogen synthase kinase-3 from rabbit skeletal muscle. Separation from cyclic-AMP-dependent protein kinase and phosphorylase kinase. Eur J Biochem 107: 519-527.

Eom TY, Jope RS (2009). Blocked inhibitory serine-phosphorylation of glycogen synthase kinase-3alpha/beta impairs in vivo neural precursor cell proliferation. Biol Psychiatry 66: 494-502.

Fang X, Yu SX, Lu Y, Bast Jr RC, Woodgett JR, Mills GB (2000). Phosphorylation and inactivation of glycogen synthase kinase 3 by protein kinase A. Proc Natl Acad Sci USA 97: 11960-11965.

Fiol CJ, Williams JS, Chou CH, Wang QM, Roach PJ, Andrisani OM (1994). A secondary phosphorylation of CREB341 at Ser129 is required for the CAMP-mediated control of gene expression. A role for glycogen synthase kinase- 3 in the control of gene expression. J Biol Chem 269: 32187-32193.

Force T, Woodgett JR (2009). Unique and overlapping functions of GSK-3 isoforms in cell differentiation and proliferation and cardiovascular development. J Biol Chem 284: 9643-9647.

Frame S, Cohen P (2001). GSK3 takes centre stage more than 20 years after its discovery. Biochem J 359(Part 1): 1-16.

Fukumoto T, Morinobu S, Okamoto Y, Kagaya A, Yamawaki S (2001). Chronic lithium treatment increases the expression of brain-derived neurotrophic factor in the rat brain. Psychopharmacology (Berl) 158: 100-106.

Goode N, Hughes K, Woodgett JR, Parker PJ (1992). Differential regulation of glycogen synthase kinase- 3 beta by protein kinase $\mathrm{C}$ isotypes. J Biol Chem 267: 16878-16882.

Goold RG, Owen R, Gordon-Weeks PR (1999). Glycogen synthase kinase 3 beta phosphorylation of microtubule-associated protein $1 \mathrm{~B}$ regulates the stability of microtubules in growth cones. $J$ Cell Sci 112(Part 19): 3373-3384. 
Gould TD, Einat H, Bhat R, Manji HK (2004). AR-A014418, a selective GSK-3 inhibitor, produces antidepressant-like effects in the forced swim test. Int J Neuropsychopharmacol 7: 387-390.

Gould TD, Einat H, O’Donnell KC, Picchini AM, Schloesser RJ, Manji HK (2007). Beta-catenin overexpression in the mouse brain phenocopies lithium-sensitive behaviors. Neuropsychopharmacology 32: 2173-2183.

Gould TD, O'Donnell KC, Picchini AM, Dow ER, Chen G, Manji HK (2008). Generation and behavioral characterization of beta-catenin forebrain-specific conditional knock-out mice. Behav Brain Res 189: $117-125$.

Grimes CA, Jope RS (2001). CREB DNA binding activity is inhibited by glycogen synthase kinase- 3 beta and facilitated by lithium. I Neurochem 78: 1219-1232.

Gurvich N, Klein PS (2002). Lithium and valproic acid: parallels and contrasts in diverse signaling contexts. Pharmacol Ther 96: 45-66.

Hall AC, Brennan A, Goold RG, Cleverley K, Lucas FR, GordonWeeks PR et al (2002). Valproate regulates GSK-3-mediated axonal remodeling and synapsin I clustering in developing neurons. Mol Cell Neurosci 20: 257-270.

Hartigan JA, Xiong WC, Johnson GV (2001). Glycogen synthase kinase 3beta is tyrosine phosphorylated by PYK2. Biochem Biophys Res Commun 284: 485-489.

Hashimoto R, Senatorov V, Kanai H, Leeds P, Chuang DM (2003). Lithium stimulates progenitor proliferation in cultured brain neurons. Neuroscience 117: 55-61.

Hayley S, Poulter MO, Merali Z, Anisman H (2005). The pathogenesis of clinical depression: stressor- and cytokine-induced alterations of neuroplasticity. Neuroscience 135: 659-678.

Hedgepeth CM, Conrad LJ, Zhang J, Huang HC, Lee VM, Klein PS (1997). Activation of the Wnt signaling pathway: a molecular mechanism for lithium action. Dev Biol 185: 82-91.

Henderson BR (2000). Nuclear-cytoplasmic shuttling of APC regulates beta-catenin subcellular localization and turnover. Nat Cell Biol 2: 653-660.

Hoeflich KP, Luo J, Rubie EA, Tsao MS, Jin O, Woodgett JR (2000). Requirement for glycogen synthase kinase-3beta in cell survival and NF-kappaB activation. Nature 406: 86-90.

Hu X, Paik PK, Chen J, Yarilina A, Kockeritz L, Lu TT et al (2006). IFNgamma suppresses IL-10 production and synergizes with TLR2 by regulating GSK3 and CREB/AP-1 proteins. Immunity 24: 563-574.

Hughes K, Nikolakaki E, Plyte SE, Totty NF, Woodgett JR (1993). Modulation of the glycogen synthase kinase- 3 family by tyrosine phosphorylation. Embo J 12: 803-808.

Inkster B, Nichols TE, Saemann PG, Auer DP, Holsboer F, Muglia P et al (2009). Association of GSK3beta polymorphisms with brain structural changes in major depressive disorder. Arch Gen Psychiatry 66: 721-728.

Jans LA, Riedel WJ, Markus CR, Blokland A (2007). Serotonergic vulnerability and depression: assumptions, experimental evidence and implications. Mol Psychiatry 12: 522-543.

Januel D, Massot O, Poirier MF, Olie JP, Fillion G (2002). Interaction of lithium with 5-HT(1B) receptors in depressed unipolar patients treated with clomipramine and lithium $v s$ clomipramine and placebo: preliminary results. Psychiatry Res 111: 117-124.

Jin N, Kovacs AD, Sui Z, Dewhurst S, Maggirwar SB (2005). Opposite effects of lithium and valproic acid on trophic factor deprivationinduced glycogen synthase kinase-3 activation, c-Jun expression and neuronal cell death. Neuropharmacology 48: 576-583.

Johnson-Farley NN, Travkina T, Cowen DS (2006). Cumulative activation of akt and consequent inhibition of glycogen synthase kinase- 3 by brain-derived neurotrophic factor and insulin-like growth factor-1 in cultured hippocampal neurons. J Pharmacol Exp Ther 316: 1062-1069.

Jope RS, Johnson GVW (2004). The glamour and gloom of glycogen synthase kinase-3. Trehds in Biochemical Sci 29: 95-102.

Kaidanovich-Beilin O, Lipina TV, Takao K, van Eede M, Hattori S, Laliberte $\mathrm{C}$ et al (2009). Abnormalities in brain structure and behavior in GSK-3alpha mutant mice. Mol Brain 2: 35 .

Kaidanovich-Beilin O, Milman A, Weizman A, Pick CG, EldarFinkelman H (2004). Rapid antidepressive-like activity of specific glycogen synthase kinase- 3 inhibitor and its effect on beta-catenin in mouse hippocampus. Biol Psychiatry 55: 781-784.

Kang UG, Seo MS, Roh MS, Kim Y, Yoon SC, Kim YS (2004). The effects of clozapine on the GSK-3-mediated signaling pathway. FEBS Lett 560: 115-119.

Karege F, Perroud N, Burkhardt S, Schwald M, Ballmann E, La Harpe $\mathrm{R}$ et al (2007). Alteration in kinase activity but not in protein levels of protein kinase B and glycogen synthase kinase-3beta in ventral prefrontal cortex of depressed suicide victims. Biol Psychiatry 61: 240-245.

Kim AJ, Shi Y, Austin RC, Werstuck GH (2005). Valproate protects cells from ER stress-induced lipid accumulation and apoptosis by inhibiting glycogen synthase kinase-3. J Cell Sci 118(Part 1): 89-99.

Kim NR, Park SW, Lee JG, Kim YH (2008). Protective effects of olanzapine and haloperidol on serum withdrawal-induced apoptosis in SH-SY5Y cells. Prog Neuropsychopharmacol Biol Psychiatry 32: 633-642.

Kim WY, Wang X, Wu Y, Doble BW, Patel S, Woodgett JR et al (2009). GSK-3 is a master regulator of neural progenitor homeostasis. Nat Neurosci 12: 1390-1397.

Klein PS, Melton DA (1996). A molecular mechanism for the effect of lithium on development. Proc Natl Acad Sci USA 93: 8455-8459.

Kockeritz L, Doble B, Patel S, Woodgett JR (2006). Glycogen synthase kinase-3 - an overview of an over-achieving protein kinase. Curr Drug Targets 7: 1377-1388.

Kozlovsky N, Amar S, Belmaker RH, Agam G (2006). Psychotropic drugs affect Ser9-phosphorylated GSK-3beta protein levels in rodent frontal cortex. Int J Neuropsychopharmacol 9: 337-342.

Kozlovsky N, Belmaker RH, Agam G (2000). Low GSK-3beta immunoreactivity in postmortem frontal cortex of schizophrenic patients. Am J Psychiatry 157: 831-833.

Lamarre M, Desrosiers RR (2008). Up-regulation of protein 1isoaspartyl methyltransferase expression by lithium is mediated by glycogen synthase kinase- 3 inactivation and beta-catenin stabilization. Neuropharmacology 55: 669-676.

Lesort M, Greendorfer A, Stockmeier C, Johnson GV, Jope RS (1999a). Glycogen synthase kinase-3beta, beta-catenin, and tau in postmortem bipolar brain. J Neural Transm 106: 1217-1222.

Lesort M, Jope RS, Johnson GV (1999b). Insulin transiently increases tau phosphorylation: involvement of glycogen synthase kinase3beta and Fyn tyrosine kinase. J Neurochem 72: 576-584.

Li M, Wang X, Meintzer MK, Laessig T, Birnbaum MJ, Heidenreich KA (2000). Cyclic AMP promotes neuronal survival by phosphorylation of glycogen synthase kinase 3beta. Mol Cell Biol 20: 93569363.

Li X, Friedman AB, Roh MS, Jope RS (2005). Anesthesia and postmortem interval profoundly influence the regulatory serine phosphorylation of glycogen synthase kinase-3 in mouse brain. J Neurochem 92: 701-704.

Li X, Friedman AB, Zhu W, Wang L, Boswell S, May RS et al (2007a). Lithium regulates glycogen synthase kinase-3beta in human peripheral blood mononuclear cells: implication in the treatment of bipolar disorder. Biol Psychiatry 61: 216-222.

Li X, Rosborough KM, Friedman AB, Zhu W, Roth KA (2007b). Regulation of mouse brain glycogen synthase kinase- 3 by atypical antipsychotics. Int J Neuropsychopharmacol 10: 7-19.

Li X, Zhu W, Roh MS, Friedman AB, Rosborough K, Jope RS (2004). In vivo regulation of glycogen synthase kinase-3beta (GSK3beta) by serotonergic activity in mouse brain. Neuropsychopharmacology 29: 1426-1431.

Liang MH, Chuang DM (2006). Differential roles of glycogen synthase kinase-3 isoforms in the regulation of transcriptional activation. J Biol Chem 281: 30479-30484.

Liang MH, Chuang DM (2007). Regulation and function of glycogen synthase kinase-3 isoforms in neuronal survival. J Biol Chem 282: 3904-3917.

Lie DC, Song H, Colamarino SA, Ming GL, Gage FH (2004). Neurogenesis in the adult brain: new strategies for central nervous system diseases. Annu Rev Pharmacol Toxicol 44: 399-421.

Lotrich FE, Ferrell RE, Rabinovitz M, Pollock BG (2009). Risk for depression during interferon-alpha treatment is affected by 
the serotonin transporter polymorphism. Biol Psychiatry 65: 344-348.

Lucas JJ, Hernandez F, Gomez-Ramos P, Moran MA, Hen R, Avila J (2001). Decreased nuclear beta-catenin, tau hyperphosphorylation and neurodegeneration in GSK-3beta conditional transgenic mice. Embo J 20: 27-39.

Machado-Vieira R, Manji HK, Zarate Jr CA (2009). The role of lithium in the treatment of bipolar disorder: convergent evidence for neurotrophic effects as a unifying hypothesis. Bipolar Disord 11(Suppl 2): 92-109.

Maggio N, Segal M (2009). Differential modulation of long-term depression by acute stress in the rat dorsal and ventral hippocampus. J Neurosci 29: 8633-8638.

Mai L, Jope RS, Li X (2002). BDNF-mediated signal transduction is modulated by GSK3beta and mood stabilizing agents. J Neurochem 82: $75-83$.

Malberg JE, Duman RS (2003). Cell proliferation in adult hippocampus is decreased by inescapable stress: reversal by fluoxetine treatment. Neuropsychopharmacology 28: 1562-1571.

Malberg JE, Eisch AJ, Nestler EJ, Duman RS (2000). Chronic antidepressant treatment increases neurogenesis in adult rat hippocampus. J Neurosci 20: 9104-9110.

Manev H, Uz T, Smalheiser NR, Manev R (2001). Antidepressants alter cell proliferation in the adult brain in vivo and in neural cultures in vitro. Eur J Pharmacol 411: 67-70.

Mao Y, Ge X, Frank CL, Madison JM, Koehler AN, Doud MK et al (2009). Disrupted in schizophrenia 1 regulates neuronal progenitor proliferation via modulation of GSK3beta/beta-catenin signaling. Cell 136: 1017-1031.

Martin M, Rehani K, Jope RS, Michalek SM (2005). Toll-like receptor-mediated cytokine production is differentially regulated by glycogen synthase kinase 3. Nat Immunol 6: 777-784.

Martinez A, Castro A, Medina M (2006). Glycogen Synthase Kinase 3 (GSK-3) and its Inhibitors. John Wiley and Sons: Hoboken, NJ.

Massot O, Rousselle JC, Fillion MP, Januel D, Plantefol M, Fillion G (1999). 5-HT1B receptors: a novel target for lithium. Possible involvement in mood disorders. Neuropsychopharmacology 21: 530-541.

McEwen BS (2008). Central effects of stress hormones in health and disease: understanding the protective and damaging effects of stress and stress mediators. Eur J Pharmacol 583: 174-185.

McManus EJ, Sakamoto K, Armit LJ, Ronaldson L, Shpiro N, Marquez R et al (2005). Role that phosphorylation of GSK3 plays in insulin and Wnt signalling defined by knockin analysis. Embo J 24: 1571-1583.

Meijer L, Flajolet M, Greengard P (2004). Pharmacological inhibitors of glycogen synthase kinase 3. Trends Pharmacol Sci 25: 471-480.

Millar JK, Wilson-Annan JC, Anderson S, Christie S, Taylor MS, Semple CA et al (2000). Disruption of two novel genes by a translocation cosegregating with schizophrenia. Hum Mol Genet 9: 1415-1423.

Miller AH, Maletic V, Raison CL (2009). Inflammation and its discontents: the role of cytokines in the pathophysiology of major depression. Biol Psychiatry 65: 732-741.

Mohammad MK, Al-Masri IM, Taha MO, Al-Ghussein MA, Alkhatib HS, Najjar S et al (2008). Olanzapine inhibits glycogen synthase kinase-3beta: an investigation by docking simulation and experimental validation. Eur J Pharmacol 584: 185-191.

Nibuya M, Nestler EJ, Duman RS (1996). Chronic antidepressant administration increases the expression of cAMP response element binding protein (CREB) in rat hippocampus. $J$ Neurosci 16: 2365-2372.

O'Brien SM, Scully P, Fitzgerald P, Scott LV, Dinan TG (2007). Plasma cytokine profiles in depressed patients who fail to respond to selective serotonin reuptake inhibitor therapy. J Psychiatr Res 41: 326-331.

O'Brien SM, Scully P, Scott LV, Dinan TG (2006). Cytokine profiles in bipolar affective disorder: focus on acutely ill patients. J Affect Disord 90: 263-267.

O'Brien WT, Harper AD, Jove F, Woodgett JR, Maretto S, Piccolo S et al (2004). Glycogen synthase kinase-3beta haploinsufficiency mimics the behavioral and molecular effects of lithium. $J$ Neurosci 24: 6791-6798.
O’Brien WT, Klein PS (2009). Validating GSK3 as an in vivo target of lithium action. Biochem Soc Trans 37(Part 5): 1133-1138.

Ozaki N, Chuang DM (1997). Lithium increases transcription factor binding to AP-1 and cyclic AMP-responsive element in cultured neurons and rat brain. J Neurochem 69: 2336-2344.

Pandey GN, Ren X, Rizavi HS, Dwivedi Y (2010). Glycogen synthase kinase-3beta in the platelets of patients with mood disorders: effect of treatment. J Psychiatr Res 44: 143-148.

Papkoff J, Aikawa M (1998). WNT-1 and HGF regulate GSK3 beta activity and beta-catenin signaling in mammary epithelial cells. Biochem Biophys Res Commun 247: 851-858.

Park HJ, Cui FJ, Hwang JY, Kang UG (2010). Effects of clozapine on behavioral sensitization induced by cocaine. Psychiatry Res 175: 165-170.

Park SW, Lee JG, Ha EK, Choi SM, Cho HY, Seo MK et al (2009). Differential effects of aripiprazole and haloperidol on BDNFmediated signal changes in SH-SY5Y cells. Eur Neuropsychopharmacol 19: 356-362.

Peineau S, Taghibiglou C, Bradley C, Wong TP, Liu L, Lu J et al (2007). LTP inhibits LTD in the hippocampus via regulation of GSK3beta. Neuron 53: 703-717.

Phiel CJ, Wilson CA, Lee VM, Klein PS (2003). GSK-3alpha regulates production of Alzheimer's disease amyloid-beta peptides. Nature 423: 435-439.

Phiel CJ, Zhang F, Huang EY, Guenther MG, Lazar MA, Klein PS (2001). Histone deacetylase is a direct target of valproic acid, a potent anticonvulsant, mood stabilizer, and teratogen. J Biol Chem 276: 36734-36741.

Philip NS, Carpenter LL, Tyrka AR, Price LH (2008). Augmentation of antidepressants with atypical antipsychotics: a review of the current literature. J Psychiatr Pract 14: 34-44.

Polter A, Yang S, Zmijewska AA, van Groen T, Paik JH, Depinho RA et al (2009). Forkhead box, class o transcription factors in brain: regulation and behavioral manifestation. Biol Psychiatry 65: 150-159.

Polter AM, Beurel E, Yang S, Garner R, Song L, Miller CA et al (2010). Deficiency in the inhibitory serine-phosphorylation of glycogen synthase kinase-3 increases sensitivity to mood disturbances. Neuropsychopharmacology 35: 1761-1774.

Post RM (2007). Role of BDNF in bipolar and unipolar disorder: clinical and theoretical implications. J Psychiatr Res 41: 979-990.

Prickaerts J, Moechars D, Cryns K, Lenaerts I, van Craenendonck H, Goris I et al (2006). Transgenic mice overexpressing glycogen synthase kinase 3beta: a putative model of hyperactivity and mania. J Neurosci 26: 9022-9029.

Quiroz JA, Gould TD, Manji HK (2004). Molecular effects of lithium. Mol Interv 4: 259-272.

Raison CL, Capuron L, Miller AH (2006). Cytokines sing the blues: inflammation and the pathogenesis of depression. Trends Immunol 27: 24-31.

Rao JS, Lee HJ, Rapoport SI, Bazinet RP (2008). Mode of action of mood stabilizers: is the arachidonic acid cascade a common target? Mol Psychiatry 13: 585-596.

Redrobe JP, Bourin M (1999). Evidence of the activity of lithium on 5-HT1B receptors in the mouse forced swimming test: comparison with carbamazepine and sodium valproate. Psychopharmacology (Berl) 141: 370-377.

Reichenberg A, Yirmiya R, Schuld A, Kraus T, Haack M, Morag A et al (2001). Cytokine-associated emotional and cognitive disturbances in humans. Arch Gen Psychiatry 58: 445-452.

Ren M, Senatorov VV, Chen RW, Chuang DM (2003). Postinsult treatment with lithium reduces brain damage and facilitates neurological recovery in a rat ischemia/reperfusion model. Proc Natl Acad Sci USA 100: 6210-6215.

Riad M, Garcia S, Watkins KC, Jodoin N, Doucet E, Langlois X et al (2000). Somatodendritic localization of 5-HT1A and preterminal axonal localization of 5-HT1B serotonin receptors in adult rat brain. J Comp Neurol 417: 181-194.

Rivest S (2009). Regulation of innate immune responses in the brain. Nat Rev Immunol 9: 429-439.

Roh MS, Eom TY, Zmijewska AA, De Sarno P, Roth KA, Jope RS (2005). Hypoxia activates glycogen synthase kinase-3 in mouse 
brain in vivo: protection by mood stabilizers and imipramine. Biol Psychiatry 57: 278-286.

Roh MS, Seo MS, Kim Y, Kim SH, Jeon WJ, Ahn YM et al (2007). Haloperidol and clozapine differentially regulate signals upstream of glycogen synthase kinase 3 in the rat frontal cortex. Exp Mol Med 39: 353-360.

Rosa AO, Kaster MP, Binfare RW, Morales S, Martin-Aparicio E, Navarro-Rico ML et al (2008). Antidepressant-like effect of the novel thiadiazolidinone NP031115 in mice. Prog Neuropsychopharmacol Biol Psychiatry 32: 1549-1556.

Roumestan C, Michel A, Bichon F, Portet K, Detoc M, Henriquet C et al (2007). Anti-inflammatory properties of desipramine and fluoxetine. Respir Res 8: 35.

Rubinfeld B, Albert I, Porfiri E, Fiol C, Munemitsu S, Polakis P (1996). Binding of GSK3beta to the APC-beta-catenin complex and regulation of complex assembly. Science 272: 1023-1026.

Ryves WJ, Dalton EC, Harwood AJ, Williams RS (2005). GSK-3 activity in neocortical cells is inhibited by lithium but not carbamazepine or valproic acid. Bipolar Disord 7: 260-265.

Ryves WJ, Harwood AJ (2001). Lithium inhibits glycogen synthase kinase- 3 by competition for magnesium. Biochem Biophys Res Commun 280: 720-725.

Salinas PC (1999). Wnt factors in axonal remodelling and synaptogenesis. Biochem Soc Symp 65: 101-109.

Santarelli L, Saxe M, Gross C, Surget A, Battaglia F, Dulawa S et al (2003). Requirement of hippocampal neurogenesis for the behavioral effects of antidepressants. Science 301: 805-809.

Sari Y (2004). Serotonin1B receptors: from protein to physiological function and behavior. Neurosci Biobehav Rev 28: 565-582.

Schloesser RJ, Huang J, Klein PS, Manji HK (2008). Cellular plasticity cascades in the pathophysiology and treatment of bipolar disorder. Neuropsychopharmacology 33: 110-133.

Schmid CL, Raehal KM, Bohn LM (2008). Agonist-directed signaling of the serotonin 2A receptor depends on beta-arrestin-2 interactions in vivo. Proc Natl Acad Sci USA 105: 1079-1084.

Schmidt HD, Duman RS (2007). The role of neurotrophic factors in adult hippocampal neurogenesis, antidepressant treatments and animal models of depressive-like behavior. Behav Pharmacol 18: 391-418.

Schotte A, Bonaventure P, Janssen PF, Leysen JE (1995). In vitro receptor binding and in vivo receptor occupancy in rat and guinea pig brain: risperidone compared with antipsychotics hitherto used. Jpn J Pharmacol 69: 399-412.

Shaltiel G, Chen G, Manji HK (2007). Neurotrophic signaling cascades in the pathophysiology and treatment of bipolar disorder. Curr Opin Pharmacol 7: 22-26.

Silva R, Mesquita AR, Bessa J, Sousa JC, Sotiropoulos I, Leao P et al (2008). Lithium blocks stress-induced changes in depressive-like behavior and hippocampal cell fate: the role of glycogen-synthasekinase-3beta. Neuroscience 152: 656-669.

Song L, De Sarno P, Jope RS (2002). Central role of glycogen synthase kinase-3beta in endoplasmic reticulum stress-induced caspase-3 activation. J Biol Chem 277: 44701-44708.

Spittaels K, Van den Haute C, Van Dorpe J, Geerts H, Mercken M, Bruynseels $\mathrm{K}$ et al (2000). Glycogen synthase kinase-3beta phosphorylates protein tau and rescues the axonopathy in the central nervous system of human four-repeat tau transgenic mice. I Biol Chem 275: 41340-41349.

Spittaels K, Van den Haute C, Van Dorpe J, Terwel D, Vandezande K, Lasrado $\mathrm{R}$ et al (2002). Neonatal neuronal overexpression of glycogen synthase kinase- 3 beta reduces brain size in transgenic mice. Neuroscience 113: 797-808.

St Clair D, Blackwood D, Muir W, Carothers A, Walker M, Spowart G et al (1990). Association within a family of a balanced autosomal translocation with major mental illness. Lancet 336: 13-16.

Stambolic V, Ruel L, Woodgett JR (1996). Lithium inhibits glycogen synthase kinase-3 activity and mimics wingless signalling in intact cells. Curr Biol 6: 1664-1668.

Stambolic V, Woodgett JR (1994). Mitogen inactivation of glycogen synthase kinase-3 beta in intact cells via serine 9 phosphorylation. Biochem J 303(Part 3): 701-704.
Sutherland C, Cohen P (1994). The alpha-isoform of glycogen synthase kinase-3 from rabbit skeletal muscle is inactivated by p70 S6 kinase or MAP kinase-activated protein kinase-1 in vitro. FEBS Lett 338: 37-42.

Sutherland C, Leighton IA, Cohen P (1993). Inactivation of glycogen synthase kinase- 3 beta by phosphorylation: new kinase connections in insulin and growth-factor signalling. Biochem J 296(Part 1): 15-19.

Szczepankiewicz A, Rybakowski JK, Suwalska A, Skibinska M, Leszczynska-Rodziewicz A, Dmitrzak-Weglarz M et al (2006). Association study of the glycogen synthase kinase-3beta gene polymorphism with prophylactic lithium response in bipolar patients. World J Biol Psychiatry 7: 158-161.

Takahashi-Yanaga F, Shiraishi F, Hirata M, Miwa Y, Morimoto S, Sasaguri T (2004). Glycogen synthase kinase-3beta is tyrosinephosphorylated by MEK1 in human skin fibroblasts. Biochem Biophys Res Commun 316: 411-415.

Thome J, Sakai N, Shin K, Steffen C, Zhang YJ, Impey S et al (2000). cAMP response element-mediated gene transcription is upregulated by chronic antidepressant treatment. J Neurosci 20: 4030-4036.

Thornton TM, Pedraza-Alva G, Deng B, Wood CD, Aronshtam A, Clements JL et al (2008). Phosphorylation by p38 MAPK as an alternative pathway for GSK3beta inactivation. Science 320: 667-670.

Toledo EM, Colombres M, Inestrosa NC (2008). Wnt signaling in neuroprotection and stem cell differentiation. Prog Neurobiol 86: 281-296.

Tsai SJ, Liou YJ, Hong CJ, Yu YW, Chen TJ (2008). Glycogen synthase kinase-3beta gene is associated with antidepressant treatment response in Chinese major depressive disorder. Pharmacogenomics J 8: 384-390.

Wang QM, Park IK, Fiol CJ, Roach PJ, DePaoli-Roach AA (1994). Isoform differences in substrate recognition by glycogen synthase kinases 3 alpha and 3 beta in the phosphorylation of phosphatase inhibitor 2. Biochemistry 33: 143-147.

Warner-Schmidt JL, Duman RS (2007). VEGF is an essential mediator of the neurogenic and behavioral actions of antidepressants. Proc Natl Acad Sci USA 104: 4647-4652.

Watcharasit P, Bijur GN, Zmijewski JW, Song L, Zmijewska A, Chen $\mathrm{X}$ et al (2002). Direct, activating interaction between glycogen synthase kinase-3beta and p53 after DNA damage. Proc Natl Acad Sci USA 99: 7951-7955.

Werstuck GH, Kim AJ, Brenstrum T, Ohnmacht SA, Panna E, Capretta A (2004). Examining the correlations between GSK-3 inhibitory properties and anti-convulsant efficacy of valproate and valproaterelated compounds. Bioorg Med Chem Lett 14: 5465-5467.

Wexler EM, Geschwind DH, Palmer TD (2008). Lithium regulates adult hippocampal progenitor development through canonical Wnt pathway activation. Mol Psychiatry 13: 285-292.

Woodgett JR (1990). Molecular cloning and expression of glycogen synthase kinase-3/factor A. Embo J 9: 2431-2438.

Yang ES, Wang H, Jiang G, Nowsheen S, Fu A, Hallahan DE et al (2009). Lithium-mediated protection of hippocampal cells involves enhancement of DNA-PK-dependent repair in mice. J Clin Invest 119: 1124-1135.

Yao HB, Shaw PC, Wong CC, Wan DC (2002). Expression of glycogen synthase kinase-3 isoforms in mouse tissues and their transcription in the brain. J Chem Neuroanat 23: 291-297.

Yasuda S, Liang MH, Marinova Z, Yahyavi A, Chuang DM (2009). The mood stabilizers lithium and valproate selectively activate the promoter IV of brain-derived neurotrophic factor in neurons. Mol Psychiatry 14: 51-59.

Yuskaitis CJ, Jope RS (2009). Glycogen synthase kinase-3 regulates microglial migration, inflammation, and inflammation-induced neurotoxicity. Cell Signal 21: 264-273.

Zhang F, Phiel CJ, Spece L, Gurvich N, Klein PS (2003). Inhibitory phosphorylation of glycogen synthase kinase-3 (GSK-3) in response to lithium Evidence for autoregulation of GSK-3. J Biol Chem 278: 33067-33077.

Zhang X, Gainetdinov RR, Beaulieu JM, Sotnikova TD, Burch LH, Williams RB et al (2005). Loss-of-function mutation in tryptophan hydroxylase-2 identified in unipolar major depression. Neuron 45: 11-16. 